First Peoples Child \& Family Review

An Interdisciplinary Journal Honouring the Voices, Perspectives, and Knowledges of First Peoples through Research, Critical Analyses, Stories, Standpoints and Media Reviews

\title{
POEM: Their Eyes
}

\section{Elaine M. Alec}

Volume 4, Number 2, 2009

URI: https://id.erudit.org/iderudit/1069325ar

DOI: https://doi.org/10.7202/1069325ar

See table of contents

\section{Publisher(s)}

First Nations Child and Family Caring Society of Canada

\section{ISSN}

1708-489X (print)

2293-6610 (digital)

Explore this journal

Cite this document

Alec, E. (2009). POEM: Their Eyes. First Peoples Child \& Family Review, 4(2), 9-9. https://doi.org/10.7202/1069325ar viewed online.

https://apropos.erudit.org/en/users/policy-on-use/ 


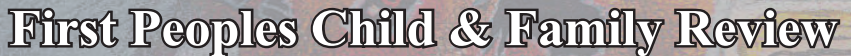

An Interdisciplinary Journal Honoring the Voices, Perspectives and Knowledges of First Peoples through Research, Critical Analyses, Stories, Standpoints and Media Reviews

\section{Volume 4, Number 2, 2009, p. 9}

\section{POEM: Their Eyes}

\author{
Elaine M. Alec
}

\section{Bio}

Elaine Alec is from the Okanagan and Shuswap Nations and lives in Penticton, British Columbia. She has been actively involved in youth rights and movement for most of her life. For more information visit http://www.myspace.com/elainealec.

When you look at each child you have to look in their eyes.

Look at the way they stare, they see, the way each cries. They all tell a story that they don't readily share.

All they want is someone to trust and someone to care.

We keep telling ourselves we do the right thing. We keep thinking they'll all fall under our wing. When you look at each child you have to look in their eyes.

When you look with an open mind you'll be surprised.

Look into their eyes, see where they are and only today.

Don't judge them on their past or shun them because they stray.

Look at today and help them see their spirit within. Don't think that you know them because you've seen where they've been.

When you look at each child you have to look in their eyes.

See how they've suffered and have had to say painful goodbyes.

Help them heal by listening without saying a thing. You'd be surprised at how much trust that can bring.

When you say you're open you have to mean it with your heart.

You can't just say you'll listen and then tear their words apart.

Each child has a story and they have such a strong voice. They need to be educated and to be given a choice.

When you look at each child you have to look in their eyes.

See how each struggles, how each really tries.

To get to the next day, to have hope to survive. They want to live, to be happy and to thrive.

When you look at each child you have to look in their eyes.

See past their actions, their anger, past their disguise. They are the centre of our community, the binding glue. They need to be put first in everything we say and do. 